consequence of an error, either of direction of attraction or of insertion of the chromosomal spindle fibres on the half-spindle spherules. This form of misdivision could be correctly called 'attractionmisdivision' or shortly ' $a$-misdivision'.

In other cases, the stretched and converged proximal ends of the telocentrics (Fig. 2) suggest a pushing away of the two arms of the daughterunivalents, produced either by the so-called stembody or by the forces assumed by Östergren to act within the spindle tactoid. This pushing away of the chromosome arms produces at first the separation of their distal ends, afterwards the stretching and finally the misdivision of the centromere. This mechanism may act too late or not strongly enough, and then the misdivision is completed by the formation of the cell wall ${ }^{5}$. This second type of misdivision can be called 'push-misdivision' or ' $p$-misdivision'.

Estación Experimental de Aula Dei, E. SÁNCHEZ-MONGE Apartado 202, Zaragoza, Spain. Aug. 19.

1 Sánchez-Monge, E., and Mackey, J, Hereditas, 34, 321 (1948).

¿ Östergren, G., Botaniska Notiser, 176 (1947),

3 Lima-de-Faria, A., Hereditas, 35, 77 (1949).

- Ustergren, G., Botaniska Notiser, 467 (1945).

s Nishiyama, I., Mem. Coll. Agric., Kyoto Imp. Univ., 32 (1934).

\section{A New Species of Root Eelworm Attacking Carrots}

IN the summer of 1944, cysts of a root eelworm were found on carrots growing on a smallholding at Chatteris in the Isle of Ely. Afterwards, infestations were noted on carrots in several other fields in the same area, some of which were alleged to have grown carrots for twenty years in succession. Where the infestation was heavy, the crop was poor and patchy. Plants lifted from the poor patches were stunted and carried an abundance of lateral roots; but this development of lateral roots was less marked than in sugar beet heavily attacked by the beet eelworm (Heterodera schachtii).

So far as I am aware, the only previous record in Great Britain of carrots being attacked by a cystforming species of Heterodera is that of Triffit. ${ }^{\text {. The }}$ species appears to be new and undescribed, and a summary of its more important features is given below.

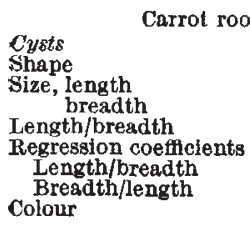

$$
\begin{aligned}
& \text { Lemon } \\
& \text { Max. } 0.68 \mathrm{~mm} \text {.; min. } 0.21 \mathrm{~mm} \text {. } \\
& \text { Max. } 0.53 \mathrm{~mm} \text {.; min. } 0.15 \mathrm{~mm} \text {. } \\
& 2.3 \text { to } 1.35 \\
& 0.6584 \pm 0.057 \\
& 0 \cdot 7084 \pm 0.059 \\
& \text { White changing to brown on death of female. } \\
& \text { No intermediate yellow stage, as in potato } \\
& \text { root eelworm } \\
& \text { Present and large, in full-grown specimens } \\
& \text { equal in size to the cyst snd containing } \\
& \text { many eggs } \\
& 454 \mu \\
& 0.33 \text { mm. } \times 0.09 \mathrm{~mm} \text {. approximately } \\
& 1.19 \mathrm{~mm} \text {. } \\
& 31.4 \mu \\
& 28 \cdot 8 \mu \\
& \text { Bi-dentate as in } H \text {. schachtii } \\
& \text { Only cultivated and wild carrot attacked out }
\end{aligned}
$$$$
\begin{gathered}
\text { Gelatinous egg sac } \begin{array}{c}
\text { Present and large, in full-grown specimens } \\
\text { equal in size to the cyst snd containing } \\
\text { many eggs }
\end{array}
\end{gathered}
$$$$
\text { Larvoe }
$$$$
\text { Male cysts }
$$$$
\text { Size on rupturing }
$$$$
\text { cortex }
$$$$
\text { Males }
$$$$
\text { Size, length }
$$$$
\text { breadth }
$$$$
\text { Copulatory spicule }
$$

Host range of 106 plants tested, including the hosts
$H$. caroto falls into the group of Heteroderarspecies in which the male has copulatory spicules with bidentate tips, as in $H$. schachtii and $H$. cruciferce. On this character alone it can be distinguished from the other species. From $H$. schachtii it differs considerably in size and shape, and in the possession of a large egg sac into which many eggs are extruded. From $H$. cruciferce it can be distinguished by its smallor size, by differences in its length-breadth relationships and in host-range. In addition, the larval length of $H$. cruciferce is given as $418 \mu$ by Franklin', whereas that of $H$. carotoe is $454 \mu$.

An account of $H$. carotoe and of observations on other species of Heterodera is being prepared for publication elsewhere.

School of Agriculture,

$$
\text { F. G. W. JoNES }
$$

Cambridge.

Aug. 30.

1 Triffit, M. J., J. Helminth., 18, 3 (1935).

${ }^{2}$ Franklin, M. T., J. Helminth., 21, 2 and 3 (1945).

\section{Blinking and Sleep}

As normal blinking is involuntary, it might be expected that blinking would proceed at its normal or at a somewhat reduced rate during sleep, as with breathing and the heart-beat. This is not so, however, though little seems to have been published on the subject, especially on the quantitative side. Whereas many of the muscles are relaxed during sleep, "the muscular tone of the muscles which keep the eyes closed is undoubtedly increased". Duke-Elder ${ }^{1}$ states that the occurrence of bilateral blinking movements "may be used as a test for the simulation of sleep".

My interest in the subject has prompted me to utilize the relatively few opportunities open to a physicist to examine the problem on a number of children and on several adults. In all cases so far examined, it has been found that in sleep the eyelids are quiescent, and show no signs whatsoever of blinking movements.

During a recent long train journey, opportunity was afforded of examining the problem in its quantitative aspects, the subjects being a young man and his wife, both of whom fell asleep several times during the course of the journey. Their interblink periods were determined when awake (eyes open), when resting with closed eyes, and observations were continued for up to $15 \mathrm{~min}$. after they had fallon asleep. In each case the conditions of the individual tests were clearly as nearly identical as was possible, and check determinations could be made; the subjects were quite unaware that they were under observation. The results are incorporated in the accompany. ing table. It did not prove practicable to obtain an accurate determination of the interblink period of the male resting with closed eyes, owing to the rapid onset of sleep in his case; but accuracy was possible with the female, who rested with closed eyes occasionally for a period greater than ten minutes.

\begin{tabular}{|l|c|c|}
\hline \multirow{2}{*}{ Condition of subject } & Interblink period \\
\cline { 2 - 3 } & Male & Female \\
\hline $\begin{array}{l}\text { Awske (eyes open) } \\
\text { Resting (eyes closed) }\end{array}$ & $\begin{array}{c}2.0 \text { sec. } \\
\text { Asleep }\end{array}$ & $\begin{array}{c}1.6 \text { sec. } \\
1.6 \text { sec. } \\
\infty\end{array}$ \\
\hline
\end{tabular}

